\title{
A MINOR NI-CU-DEPOSIT AT TELKKÄLÄ, SE-FINLAND
}

\author{
T. A. Häkli, M. Huhma, E. Viluksela and Y. Vuorelainen
}

Häkli, T. A; Huhma, M; Viluksela, E. and Vuorelainen, Y. 1975: A minor Ni-Cu-deposit at Telkkälä, SE-Finland. Bull. Geol. Soc. Finland 47, 55-70.

The Telkkälä Ni-Cu-deposit is situated in SE Finland about $16 \mathrm{~km} \mathrm{NW}$ of the town of Lappeenranta. The mineralization, which is in association with a differentiated mafic pipe-like body, was the object of mining activities of the Outokumpu Co. in 1969 and 1970. During that time 211331 tons of ore and 122500 tons of barren rock were hoisted from the open pit. The ore averaged $1.06 \% \mathrm{Ni}$ and $0.29 \% \mathrm{Cu}$.

The rocks in the mafic body range from the central peridotites to perknites, pyroxenites and gabbros that occur as concentric zones around the ultramafic core. The basic body is enveloped by a garnet-rich and cordierite-bearing gneissose rock that has been interpreted as a product of thermometamorphism due to hot basic magma reacting with the surrounding argillaceous sediments.

Disseminated ore with fairly fresh sulphides is mainly restricted to the cummingtonite gabbro. High-grade breccia ores favour peridotites and perknites whereas massive and stringer ores occur in almost every rock type. The massive ores exhibit intensive alterations, the pyrrhotite and pentlandite having largely been replaced by pyrite, marcasite, bravoite and violarite.

The elemental distribution and the correlations between the ore-forming components suggest that the mineralization process was controlled by four factors at least.

Lead isotope studies on the sulphides show them to be very rich in radiogenic lead, which obviously derives from the adjacent mica gneiss. The lead isochron gives an age of $1820 \mathrm{Ma}$ for the orebody. This is in excellent agreement with the Svecofennian common lead ages for sulphides.

T. A. Häkli, M. Hubma, E. Viluksela and Y. Vuorelainen Outokumpu Co., P.O. Box 27, 02101 Espoo 10, Finland.

\section{Introduction}

While digging the foundation for a cellar in the 1930's near his farm in the village of Telkkälä at Taipalsaari, SE Finland, Mr. Taavetti Tölli came across a rusty soil underlain by bedrock in which there was a cavity large enough for a man to crawl into. Although the discovery aroused Mr. Tölli's interest, he did not take any steps to inform the authorities about the suspected ore. After having received rusty samples from the deposit unearthed by Mr. Tölli, the Exploration 


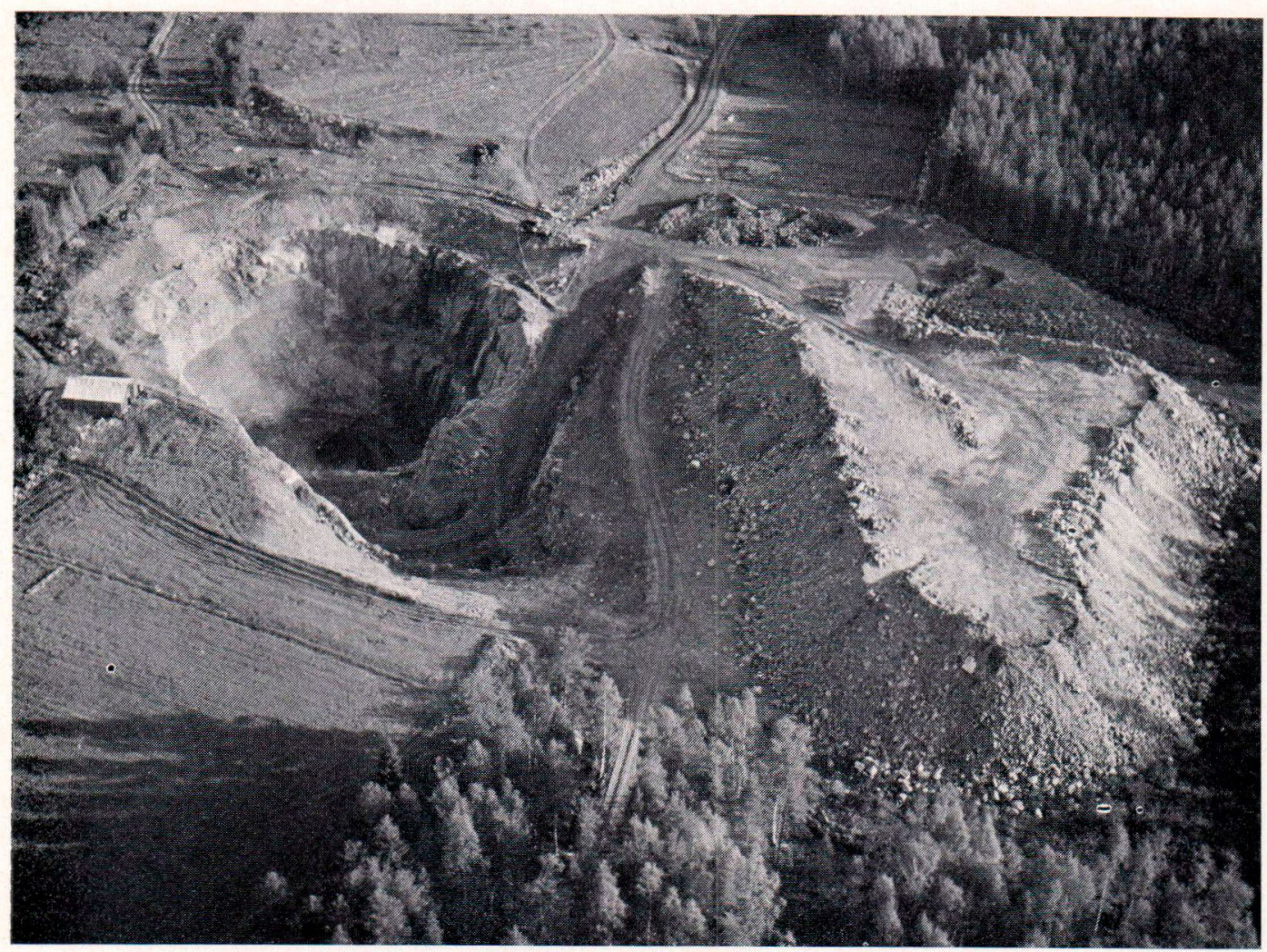

Fig. 1. Aerial view of the Telkkälä open pit during the mining operations in 1970.

Department of the Outokumpu Co. initiated magnetic, electromagnetic and gravimetric surveys in 1961, which disclosed a diminutive anomaly $70 \times 100 \mathrm{~m}$ in extent in the field next to Mr. Tölli's farm. Six small-diameter holes were subsequently drilled into the anomaly, three of which intersected high-grade nickel ore. The deposit was apparently rather small and further activities were suspended.

The nickel boom in 1968 triggered follow-ups, including feasibility studies. The deposit was penetrated with a $10 \times 10 \mathrm{~m}$ grid of vertical percussion holes from which rock cuts were analyzed at 1 metre intervals.

In addition to 63 percussion holes, 11 inclined diamond drill holes were driven into the deposit. The orebody was estimated to contain 190000 metric tons of ore, assaying $1.28 \% \mathrm{Ni}$ and $0.29 \%$ $\mathrm{Cu}$.

Open-cast mining commenced in 1969 and the deposit was exhausted by the end of 1970 (Fig. 1). During that time, 211331 tons of ore averaging $1.06 \% \mathrm{Ni}$ and $0.29 \% \mathrm{Cu}$, as well and 122500 tons of barren rock were hoisted. Most of the blasted ore, i.e. 177560 tons, was transported $165 \mathrm{kms}$ by lorry to the Virtasalmi copper mine for concentration.

The rest, 33771 tons of ore, was treated in the concentrator at the Aijala mine. The overall recovery for nickel was $93.0 \%$ and that for copper $93.1 \%$.

The exploration and exploitation activities produced a sizeable body of data pertinent to the geochemistry, petrography and mineragraphy of 


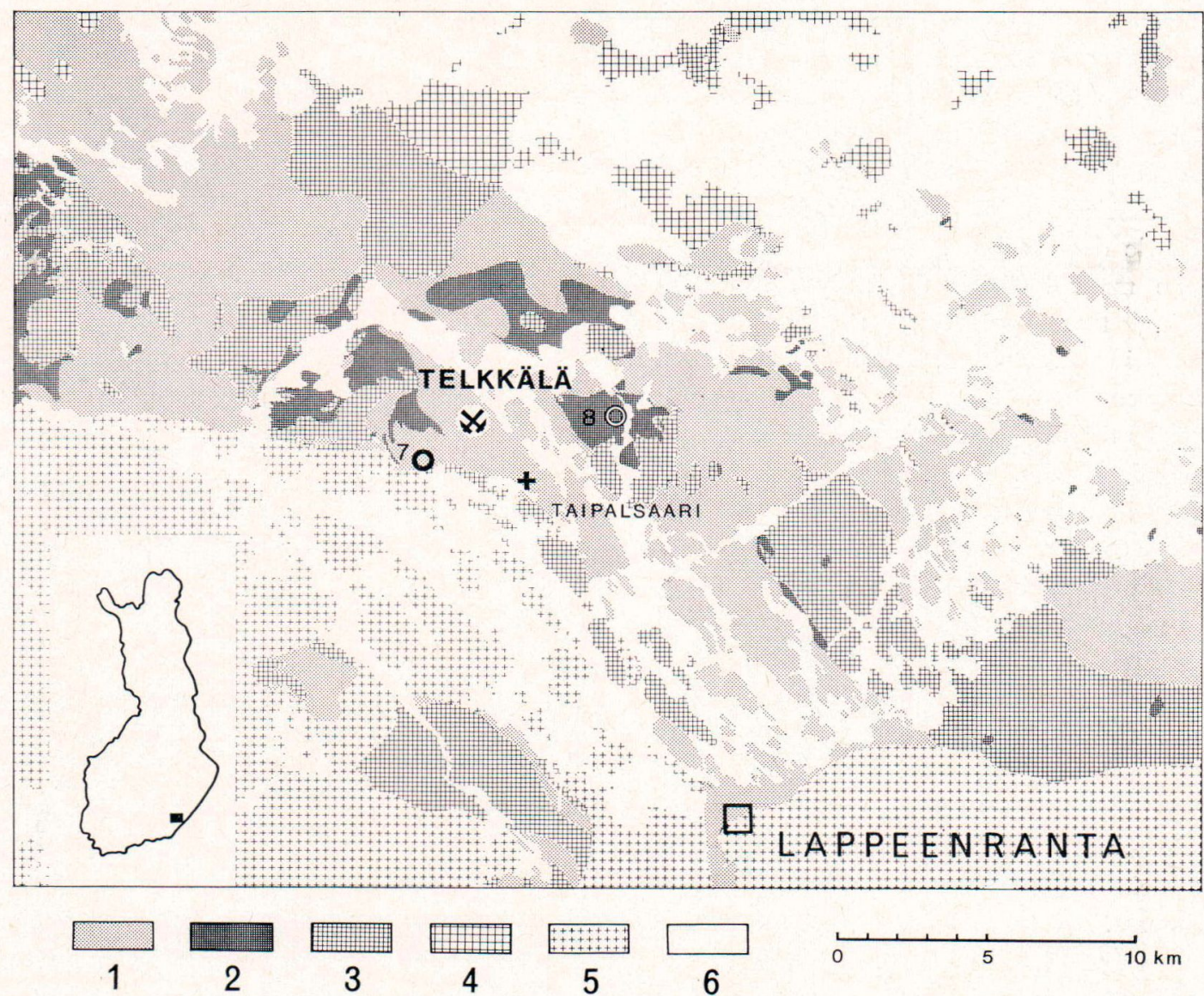

Fig. 2. Simplified geologic map of the Telkkälä region after Vorma (1965). 1. mica gneiss, 2. gabbro or diorite,

3. grano- to quartz-diorite, 4. granite, 5. rapakivi granite, 6. lakes, 7. Haikkaanlahti Ni-showing, 8. Ahokkala Ni-showing.

the deposit. Consequently, in spite of, or perhaps on account of its small size, the Telkkälä orebody is better known than some others. The aim of the present paper is to describe this deposit and present a model for its formation and postdepositional alterations.

\section{Geologic set-up}

The Telkkälä nickel deposit is located about 16 kilometres NW of Lappeenranta in SE Finland in a geologic milieu characterized by mica gneisses cut by granites and basic rocks (Fig. 2.). $8 \quad 7352-75$
Not far from it there are two other minor nickel showings: one at Ahokkala in a noritic body and the other in a tiny basic lens at Haikkaanlahti. The nickel-copper ore at Telkkälä is associated with a small mafic body whose horizontal dimensions are about $50 \times 150$ metres. On the map (Fig. 3.) it is shaped like a deformed ovoid penetrated from both sides by two mica gneiss wedges. The lower contact with mica gneiss is undulatory with a downward bulge at the southeastern end.

The major axis of the mafic body parallels the NW-SE strike of schistosity in the surrounding mica gneiss. 
This gneiss, which is often rich in garnet and cordierite, occupies the area north of the Viipuri rapakivi massif, whose northern contact is only three kilometres south of Telkkälä (Vorma 1965). Embedded in mica gneiss are several grano- to quartzdiorite bodies with frequent dioritic or gabbroic differentiates.

The mafic body is distinctly differentiated, ranging from peridotite to cummingtonite gabbro in composition. The differentiates show a concentric distribution pattern. Peridotite occupies the core, which is rimmed by a narrow zone of perknite. The outer portions are composed of cummingtonite gabbro. The rock types grade into each other without intrusive contacts between them and the whole structure seems to plunge gently towards the SE. The continuation of the basic formation in this direction is also suggested by the mise-á-la-masse survey (Ketola 1972). The contact of the mafic body with the mica gneiss is frequently marked by a garnetrich and cordierite-bearing gneissose rock that was apparently formed through the action of the hot basic magma on the surrounding argilleous sediments.

\section{Rock types}

Peridotites exhibit a widely diverse mineral composition, grading from olivine-rich variants into subperknites. The olivine grains are coarse, often fractured and filled with opaques. They are usually fresh although locally altered into serpentine. The average iron content in olivine is $15.5 \%$ and that of nickel $600 \mathrm{ppm}$, as shown by electron microprobe analyses.

The orthopyroxene averages $9.1 \% \mathrm{Fe}$ and $155 \mathrm{ppm}$ Ni. It occurs as idiomorfic plates with partly uralitizated margins, although it is also encountered in bundles of fresh and fine-grained crystals that are obviously of a younger generation than the idiomorfic ones. The amphibole fibres vary in size and fill the interstitial spaces
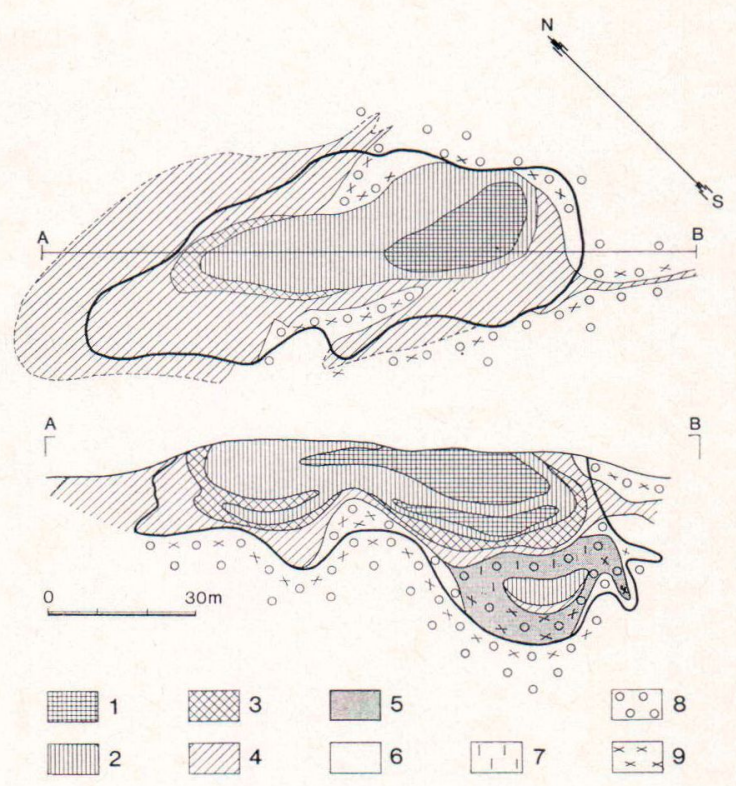

Fig. 3. Geologic map and vertical longitudinal crosssection of the Telkkälä deposit. 1. peridotite, 2. perknite, 3. norite, 4. cummingtonite gabbro, 5. massive sulphides, 6. mica gneiss, 7. ultrabasic fragments in ore, 8. garnet, 9. amphibole. The heavy line denotes the cut-off boundary.

between the other minerals. Under the microscope they are pale in colour, although some almost colourless variants are also encountered. They average $4.4 \% \mathrm{Fe}$ and $225 \mathrm{ppm} \mathrm{Ni}$.

Perknites are pyroxene-amphibole rocks whose amphibole is somewhat darker in colour and richer in iron and nickel, assaying $7.3 \% \mathrm{Fe}$ and $320 \mathrm{ppm} \mathrm{Ni}$, than it is in peridotite. Orthopyroxene also has higher abundances of iron and nickel averaging $13.4 \% \mathrm{Fe}$ and $190 \mathrm{ppm} \mathrm{Ni}$. In many places it has altered into amphiboles, of which cummingtonite is fairly common. Augite occurs as an accessory. The perknites grade into gabbros with the appearance of plagioclase.

The gabbros are medium-grained hypidiomorfic and locally orientated rocks with orthopyroxene, hornblende and cummingtonite as predominant mafic minerals. Biotite may or may not be present as a major constituent. The composition of the plagioclase fluctuates between $\mathrm{An}_{50}$ and $\mathrm{An}_{60}$, although in the variants contain- 
ing some quartz it is andesine. The average iron content in the orthopyroxene, $13.3 \% \mathrm{Fe}$, is the same as that in perknite. Its nickel abundance, $155 \mathrm{ppm} \mathrm{Ni}$, is somewhat lower, averaging that of the peridotites. In amphiboles iron and nickel assay $6.9 \% \mathrm{Fe}$ and $245 \mathrm{ppm} \mathrm{Ni}$, respectively. Biotite, chlorite, apatite, quartz, titanite, sericite, carbonates and zircon occur as accessories. The abundance of sulphides varies and often exceeds the cut-off, i.e. $0.25 \% \mathrm{Ni}$. However, the cummigtonite gabbro at the NW end is almost totally devoid of sulphides.

The composition of the gabbros grades from those of plagioclase-poor perknitic types through pale norites into cummingtonite gabbros. In places, orthopyroxene has altered into cummingtonite whose abundance increases towards the contacts with the mica gneiss. Near the mineralized portions, plagioclase, orthopyroxene and cummingtonite have altered into an almost isotropic chloritic mass.

Towards the mica gneiss, the cummingtonite gabbro grades into sulphide-poor cummingtonite gneiss with an increase of quartz and biotite. The plagioclase laths are labradoriteandesine in composition and the rock also contains hornblende in addition to cummingtonite. The field and laboratory data suggest that this rock is the product of an interaction between the hot basic magma and the country rock.

The high-grade ore contains garnet, darkgreen hornblende, quartz, oligoclase, dark-brown biotite and sometimes chloritized orthopyroxene and siderite as non-sulphidic constituents. The portions of massive ores occur close to the contacts with mica gneiss or in association with pegmatite veins. The silicates are distributed erratically in the ore occurring either as discrete grains or grain accumulations in a sulphidic matrix. Carbonates, which are mainly siderite, form veinlets of variable size.

The pegmatite veins 0.1 to $0.5 \mathrm{~m}$ in width, which crosscut the mafic body, are composed of oligoclase, microline and quartz with biotite, clorite, apatite and opaques as accessories.

\section{Ore types}

The ore minerals and their proportions vary considerably depending on the host rock. Disseminated ores, in which the sulphide blebs are either discrete or exhibit typical net structure, are mainly restricted to the cummingtonite gabbro at the NW end of the deposit (Fig. 4. and 5.). High-grade breccia ores favour peridotite and perknite, whereas massive and stringer ores occur in almost every rock type present (Fig. 6.).

The mineragraphy of the primary sulphides is fairly uniform throughout the deposit. Pyrrhotite, pentlandite and chalcopyrite are the dominant sulphides. In addition to them, sphalerite is occasionally encountered in quantities unusual for a nickel-copper ore. Ilmenite is a primary oxide, as are ilmenomagnetite, chromite and rutile, which are met with in peridotite.

Pyrrhotite occurs as interlocking, rounded to irregular grains ranging in size from $0.1 \mathrm{~mm}$ to $10 \mathrm{~cm}$. The coarse sulphides occur close to the

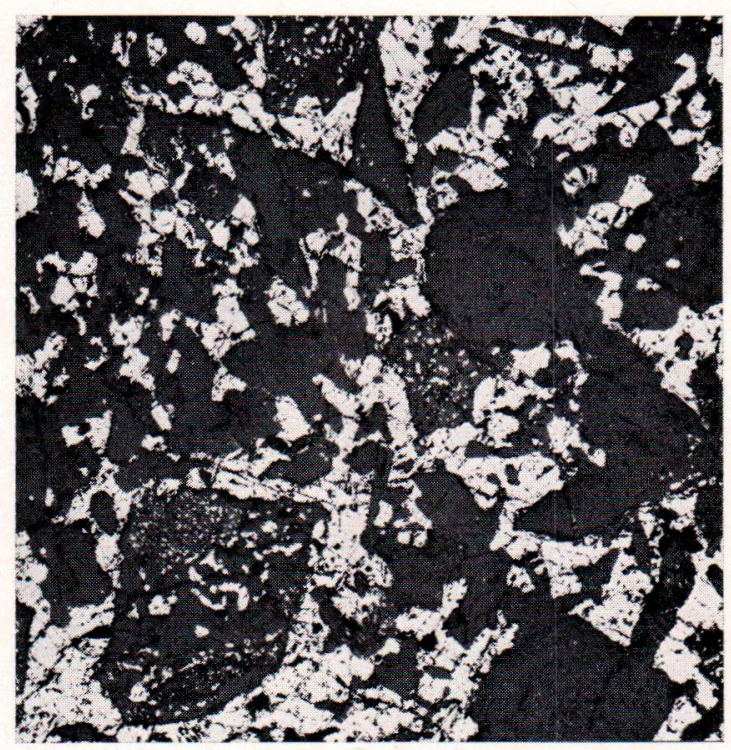

Fig. 4. Perknitic peridotite with a network of unaltered sulphide dissemination. The sulphides exhibit two generations, of which the younger and nickel-poor one occurs in and around the aggregates of the second generation orthopyroxene, $13 \mathrm{x}$. 


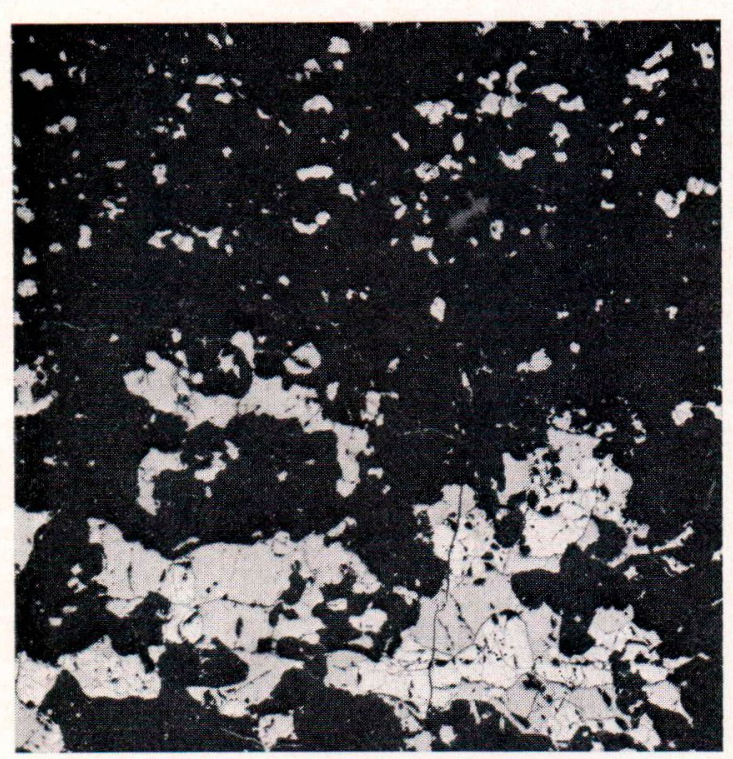

Fig. 5. Coarse- and fine-grained unaltered sulphide dissemination in a banded peridotite. Chalcopyrite fills the capillary cracks in the contact between the two ore types, $13 \mathrm{x}$.

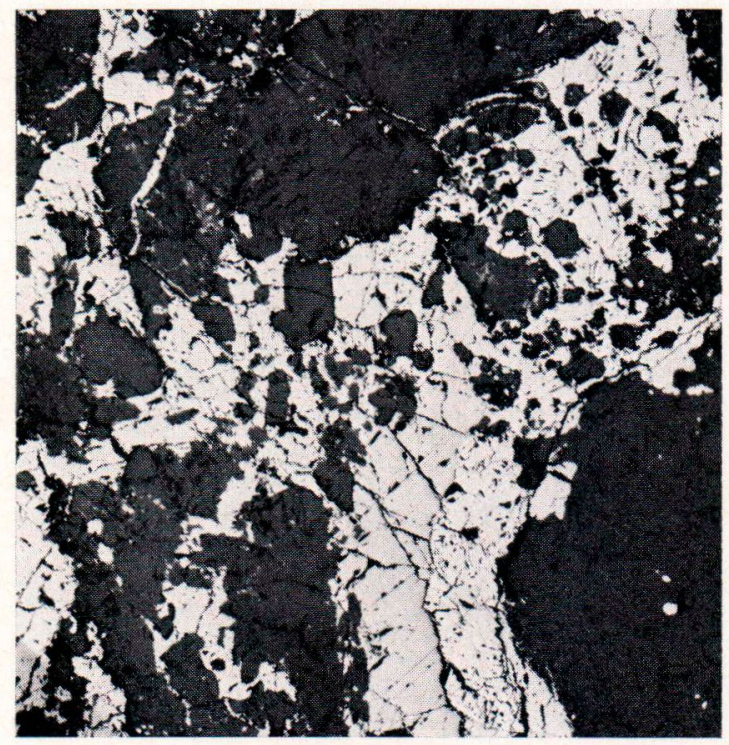

Fig. 6. Well-preserved breccia ore composed of pyrrhotite and pentlandite. The host rock is perknite, $13 \mathrm{x}$. pegmatite veins, to which they owe their coarseness. Monoclinic pyrrhotite dominates in great excess over the hexagonal variety and it is frequently fairly rich in nickel. Electron microprobe determinations indicate $0.35 \% \mathrm{Ni}$ as the average value, the abundance varying between $0.2 \%$ and $0.5 \% \mathrm{Ni}$.

Pentlandite exhibits two principal textural forms: irregular blocky grains from 0.1 to $4 \mathrm{~mm}$ in diameter interstitial to and rimming the pyrrhotite grains, and exsolved flame structures which commonly flare out from partings and cracks within the pyrrhotite. However, there are few of the latter. This fact together with the high nickel abundance in pyrrhotite is probably due to the diminutive size of the deposit and hence to the fairly high rate of cooling, which caused the exsolution process of pentlandite to $»$ freeze out» at a temperature higher than that which is common in larger deposits.

Chalcopyrite occurs as irregular blebs or wisps usually encircling the pyrrhotite and pentlandite grains adjacent to the silicates. It is also encountered as veinlets in gangue and breccia ore.

\section{Secondary alterations}

The shallow depth of the deposit and the fact that it has long been close to the surface and subject to supergene processes have given rise to the formation of secondary minerals replacing the primary sulphides. The alteration is mainly restricted to the SE part of the deposit, where the intensity of the supergene processes was highest in the massive and breccia ores, whereas the disseminated ores exhibit only slight to moderate alterations. Pyrite, marcasite, bravoite and violarite were formed as a result of these processes as were hematite, goethite and magnetite. Hematite occurs as fine-grained unconsolidated earth in association with quartz in cavities 5 to $10 \mathrm{~cm}$ in diameter, which are restricted to the 
embayment. As a consequence, considerable quantities of siderite were deposited owing to the reaction between the liberated iron and the $\mathrm{CO}_{2}$ dissolved in supergene or residual solutions.

The alteration involving the depletion of iron begins in pyrrhotite, invariably with the formation of marcasite-pyrite lamellae parallel to the basal parting (Figs. 7. and 8.). Since the volumes of the secondary disulphides are smaller than those of pyrrhotite, pyrite and marcasite are filled with pores. As the number of pores increases the surface exposed to the supergene solutions also increases, thereby accelerating the rate of alteration. Finally, the pores are filled with melnikovitic pyrite and siderite. However, the alteration did not proceed uniformly and pyrrhotite grains up to $10 \mathrm{~cm}$ in diameter have been found completely altered into pyrite (Fig. 9.), while at the same time, the adjacent grains only exhibit incipient disulphidization or are perfectly fresh.

The pyrite and marcasite crystallized in situ have nickel abundances that are slightly higher than those of the unaltered pyrrhotite, whereas the nickel tenor of the marcasite and pyrite formed in larger cavities varies greatly.

According to electron microprobs studies, the nickel abundances range from $0.03 \% \mathrm{Ni}$ to $3.50 \% \mathrm{Ni}$ in marcasite and up to $4.60 \% \mathrm{Ni}$ in bravoitic pyrite. The latter invariably shows euhedral crystal forms and concentric zonal structures, the abundance of nickel varying from zone to zone (Fig. 10.). Compared with common pyrite, the reflectance of the nickel-rich bravoite is somewhat lower and the mineral has a brownish tint. Occasionally bravoites exhibit anomalous anisotropism, which manifests itself as an anisotropic hourglass structure in polarized light.

Pentlandite has altered into violarite. The process, which begins from the margins and fractures of the grains, often seems to precede the alteration of pyrrhotite. In some samples of massive ore that have undergone thorough alteration, violarite relics are replaced either partly or completely by chalcopyrite and marcasite (Fig.

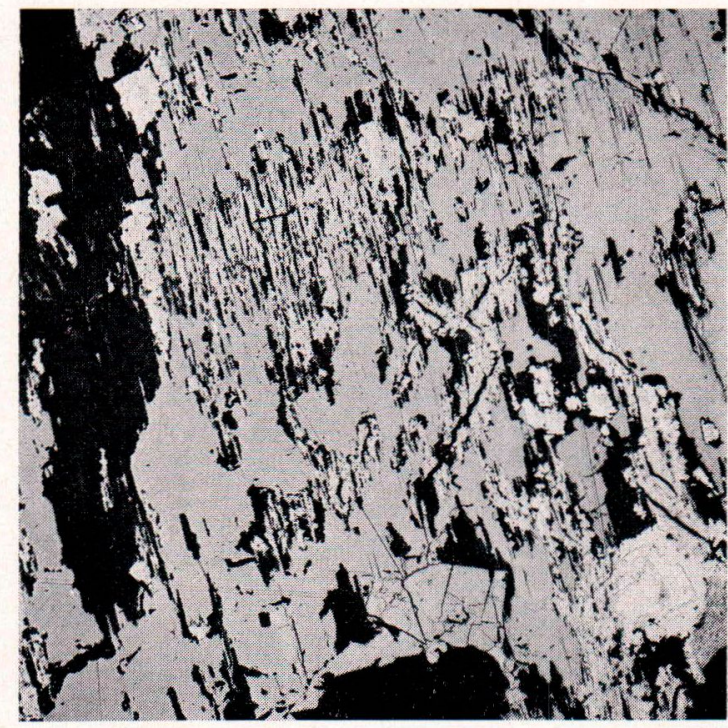

Fig. 7. Incipient alteration in pyrrhotite. Marcasite and pyrite replace pyrrhotite along 001 cleavage. Bravoite fills large amygdules produced by oxydizing agents (the lower right corner of the image). Pentlandite has altered into violarite, $50 \mathrm{x}$.

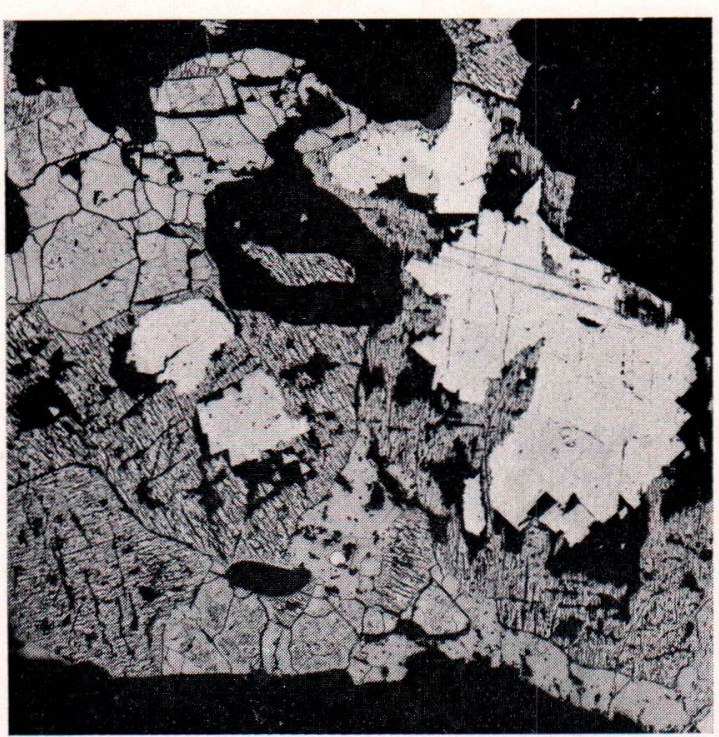

Fig. 8. Pyrite and bravoite replacing pyrrhotite in the altered ore with a gabbroic base. Pyrrhotite is characterized by distinctly developed 001 cleavage. Pentlandite has undergone violaritization (the lower left corner of the image), $50 \mathrm{x}$. 


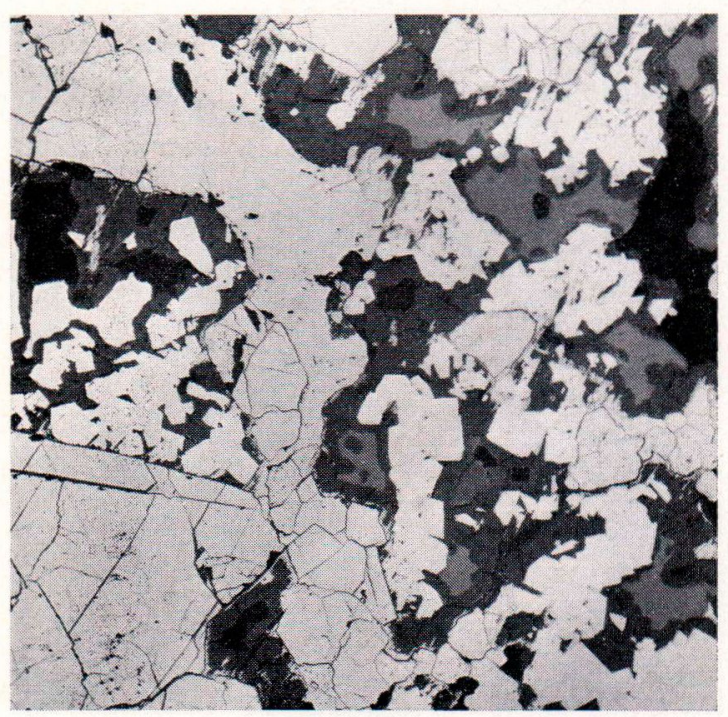

Fig. 9. Heavily altered massive ore, in which pyrrhotite has undergone pyritization and bravoitization with the simultaneous violaritization of pentlandite. The matrix between the sulphides is composed of a botryoidal mixture of iron silicates and oxides with amygdules, $13 \mathrm{x}$.
11.), while at the same time the adjacent cavities contain bravoite crystals in quantities exceeding the average. It is probable that most of the bravoite and Ni-rich marcasite crystallized at a fairly late stage, and that they owe their nickel to the disintergrated violarite.

The fracture fillings in the foot-wall country rock contain hematite, pyrite, marcasite and siderite that are practically free from nickel. This seems to indicate that the distance migrated by nickel in solution is fairly short and that this metal rapidly enters into the lattice of crystallising disulphides.

With the exception of gossan, which partly covered the deposit, the amount of oxides produced by the supergene processes is surprisingly small.

\section{Variation in elemental abundances}

The elemental distribution in the deposit is well-established owing to the dense sampling grid. Samples were collected from 91 holes, 72 of which were vertical percussion holes drilled

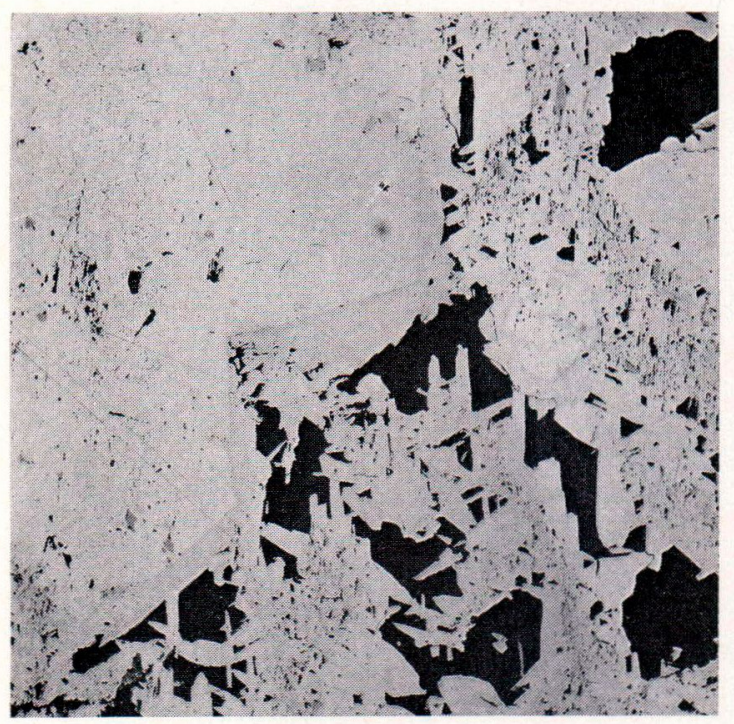

Fig. 10. Completely altered compact ore composed of zoned bravoite with variable composition and nickeliferous marcasite. Colloform iron silicates with amygduls occupy the interstities between the sulphides, $100 \mathrm{x}$.

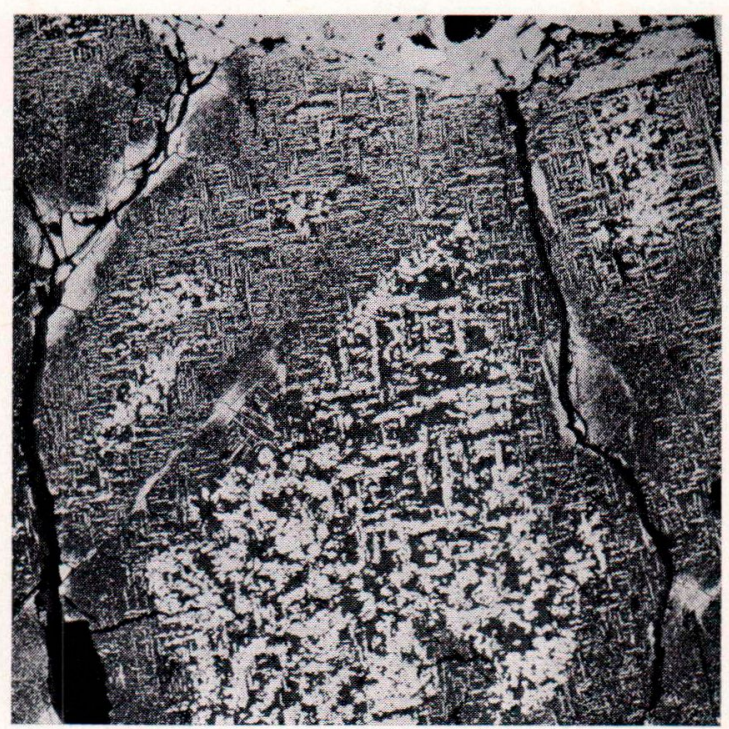

Fig. 11. Bravoite, nickeliferous marcasite and chalcopyrite replacing violarite. The matrix is botryoidal mass, $100 \mathrm{x}$. 
in a $10 \times 10 \mathrm{~m}$ grid, and the rest diamond core holes with variable inclination. The rock cuts from the percussion holes were collected as powder samples, each one corresponding to penetration of one metre. The length of the diamond core samples fluctuated around two metres depending on the rock type.
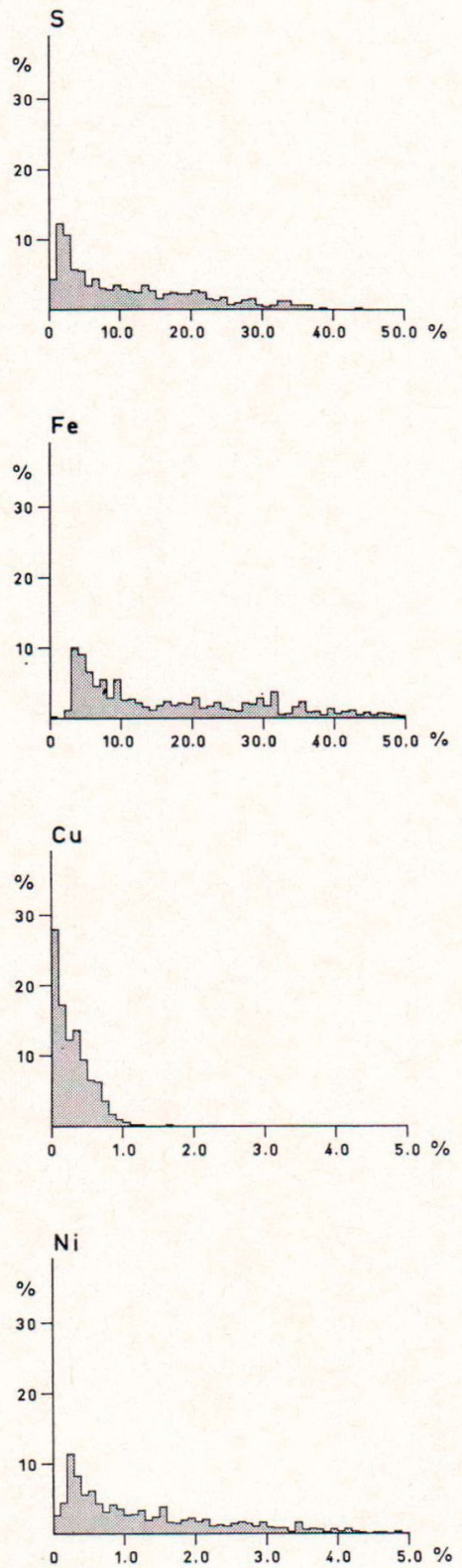

The samples, 858 in all, were analyzed by an AAS method for seven elements, i.e. $\mathrm{Cu}, \mathrm{S}, \mathrm{Fe}$, $\mathrm{Zn}, \mathrm{Ni}, \mathrm{Co}$ and $\mathrm{Pb}$ except for $\mathrm{S}$, which was determined titrimetrically.

The frequency distributions of the analyzed elements presented in Fig. 12. are all positively skewed, suggesting a roughly lognormal distri-
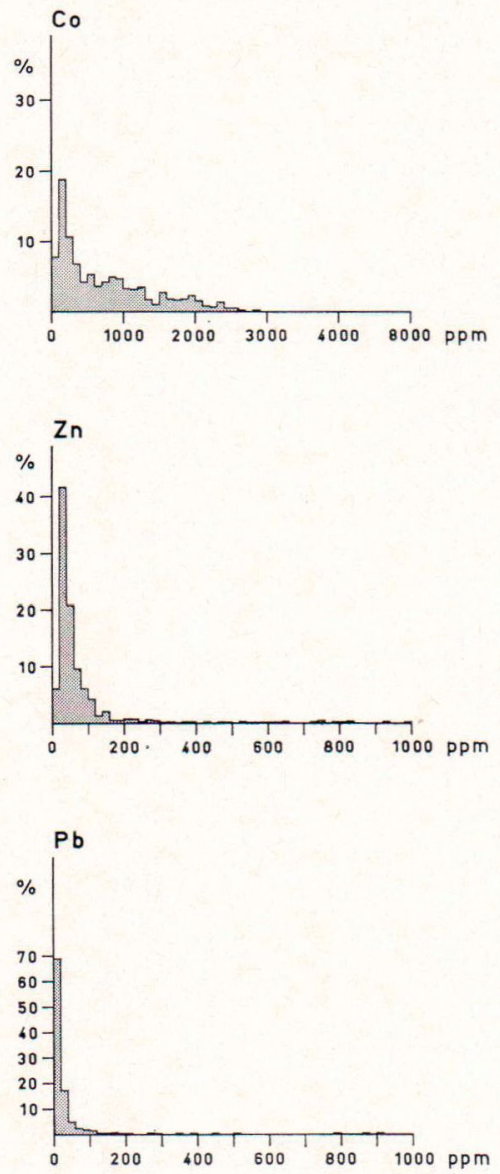

Fig. 12. Frequency distributions of $\mathrm{S}, \mathrm{Fe}, \mathrm{Cu}, \mathrm{Ni}, \mathrm{Co}, \mathrm{Zn}$ and $\mathrm{Pb}$ in the Telkkälä deposit. 
bution. The large range in the variation of the abundances of $\mathrm{S}, \mathrm{Fe}, \mathrm{Ni}$ and $\mathrm{Co}$ is a natural consequence of the fact that the mode of occurrence of sulphides varies from low grade dissemination to massive ores.

The variation in the mineragraphy, the existence of several ore types and the heavy alteration clearly indicate that the formation of the ore was not an isolated event but, rather, a succession of events encompassing a long time span that is, actually, still going on as a supergene process. Consequently, factor analysis was applied to the geochemical data, based on the logarithms of the following variables: $\mathrm{Cu}, \mathrm{S}, \mathrm{Fe}, \mathrm{Zn}, \mathrm{Co}, \mathrm{Pb}, \mathrm{Cu} / \mathrm{S}$, $\mathrm{Fe} / \mathrm{S}$ and $\mathrm{Ni} / \mathrm{Co}$, to determine which were the dominant agents contributing to the formation of the ore. A logarithmic transformation was carried out in order to bring the distributions of the variables closer to the normal ones.

The deposit is characterized by strong positive correlations between $\mathrm{Cu}, \mathrm{Ni}, \mathrm{Co}, \mathrm{Fe}$ and $\mathrm{S}$ (Table 1.). Zinc appears to lack any correlation with sulphur or any other metal with the exception of lead.

The four factors listed in Table 2 account for $85.2 \%$ of the total variance in the eleven response variables. The first factor with high loadings on $\mathrm{Cu}, \mathrm{S}, \mathrm{Fe}, \mathrm{Ni}$ and Co clearly reflects the agents that gave rise to the heavy $\mathrm{Ni}-\mathrm{Cu}$-ore formation at Telkkälä. The second factor has

TABLE 1

Correlation matrix based on 858 samples from the Telkkälä deposit

\begin{tabular}{|c|c|c|c|c|c|c|c|c|c|c|c|}
\hline & $\log \mathrm{Cu}$ & $\log S$ & $\log \mathrm{Fe}$ & $\log \mathrm{Zn}$ & $\log \mathrm{Ni}$ & $\log$ Co & $\log \mathrm{Pb}$ & $\log \mathrm{Cu} / \mathrm{S}$ & $\log \mathrm{Fe} / \mathrm{S}$ & $\log \mathrm{Ni} / \mathrm{S}$ & $\log \mathrm{Ni} / \mathrm{Co}$ \\
\hline $\log \mathrm{Cu} \ldots$ & - & 0.873 & 0.798 & -0.023 & 0.871 & 0.877 & 0.263 & 0.143 & -0.619 & -0.232 & -0.091 \\
\hline S... & 0.873 & - & 0.916 & C. 031 & 0.973 & 0.980 & 0.334 & -0.357 & -0.705 & -0.357 & -0.083 \\
\hline $\mathrm{Fe} \ldots$ & 0.798 & 0.916 & - & 0.058 & 0.882 & 0.915 & 0.349 & -0.330 & -0.361 & -0.373 & -0.219 \\
\hline $\mathrm{Zn}$. & -0.023 & 0.031 & 0.058 & - & 0.017 & 0.023 & 0.680 & -0.107 & 0.030 & -0.073 & -0.029 \\
\hline $\mathrm{Ni} \ldots$ & 0.871 & 0.975 & 0.882 & 0.017 & - & 0.978 & 0.306 & -0.312 & -0.707 & -0.141 & 0.031 \\
\hline Co $\ldots$ & 0.877 & 0.980 & 0.915 & 0.023 & 0.978 & - & 0.319 & -0.306 & -0.655 & -0.2 & -0.180 \\
\hline $\mathrm{Pb} \quad \ldots$ & 0.263 & 0.334 & 0.349 & 0.680 & 0.306 & 0.319 & - & -0.171 & -0.156 & -0.208 & -0.088 \\
\hline $\mathrm{Cu} / \mathrm{S}$ & 0.143 & -0.357 & -0.330 & -0.107 & -0.312 & -0.306 & -0.171 & - & 0.245 & 0.280 & -0.006 \\
\hline $\mathrm{Fe} / \mathrm{S}$ & -0.619 & -0.705 & -0.361 & 0.030 & -0.707 & -0.655 & -0.156 & 0.245 & - & 0.169 & -0.194 \\
\hline $\mathrm{Ni} / \mathrm{S}$. & -0.232 & -0.357 & -0.373 & -0.073 & -0.141 & -0.263 & -0.208 & 0.280 & 0.169 & - & 0.530 \\
\hline $\mathrm{Ni} / \mathrm{Co}$ & -0.091 & -0.083 & -0.219 & -0.029 & 0.031 & -0.180 & -0.088 & -0.006 & -0.194 & 0.530 & - \\
\hline
\end{tabular}

TABLE 2

Rotated factors and communalities

\begin{tabular}{|c|c|c|c|c|c|}
\hline & 1 & 2 & 3 & 4 & communalities \\
\hline $\log C u \ldots \ldots \ldots \ldots$ & 0.939 & 0.047 & -0.103 & 0.305 & 0.988 \\
\hline s $\ldots \ldots \ldots \ldots \ldots$ & 0.968 & 0.087 & -0.138 & -0.185 & 0.998 \\
\hline $\mathrm{Fe} \ldots \ldots \ldots \ldots \ldots$ & 0.855 & 0.131 & -0.309 & -0.116 & 0.858 \\
\hline $\mathrm{Zn} \ldots \ldots \ldots \ldots \ldots$ & -0.065 & 0.933 & 0.002 & -0.045 & 0.876 \\
\hline $\mathrm{Ni} \ldots \ldots \ldots \ldots$ & 0.981 & 0.077 & 0.036 & -0.130 & 0.985 \\
\hline Co $\ldots \ldots \ldots \ldots \ldots$ & 0.964 & 0.079 & -0.162 & -0.103 & 0.972 \\
\hline $\mathrm{Pb} \ldots \ldots \ldots \ldots \ldots$ & 0.250 & 0.884 & -0.096 & -0.051 & 0.857 \\
\hline $\mathrm{Cu} / \mathrm{S} \ldots \ldots \ldots \ldots$ & -0.165 & -0.086 & 0.083 & 0.962 & 0.967 \\
\hline $\mathrm{Fe} / \mathrm{S} \ldots \ldots \ldots \ldots \ldots$ & -0.737 & 0.031 & -0.227 & 0.227 & 0.647 \\
\hline $\mathrm{Ni} / \mathrm{S} \ldots \ldots \ldots \ldots \ldots$ & -0.191 & -0.071 & 0.787 & 0.278 & 0.738 \\
\hline $\mathrm{Ni} / \mathrm{Co} \ldots \ldots \ldots \ldots \ldots$ & 0.008 & -0.020 & 0.911 & -0.127 & 0.845 \\
\hline Eigen values $\ldots \ldots \ldots \ldots \ldots$ & 5.426 & 1.748 & 1.446 & 1.113 & 一 \\
\hline $\begin{array}{l}\text { Cumulative percentage of } \\
\text { total variance } \ldots \ldots \ldots \ldots\end{array}$ & 49.33 & 65.22 & 78.37 & 88.49 & - \\
\hline
\end{tabular}


strong loadings on $\mathrm{Zn}$ and $\mathrm{Pb}$ and hence, is mainly responsible for the variations in the abundances of these metals in the deposit. In the third factor high loadings are on $\mathrm{Ni} / \mathrm{S}$ and $\mathrm{Ni} / \mathrm{Co}$ and in the fourth factor the high loading is on $\mathrm{Cu} / \mathrm{S}$.

Direct comparison with the factors reported by Häkli (1970) from mafic-ultramafic rocks in Finland cannot be made, because the variables were not quite the same in both cases. However, it is obvious that the first factor at Telkkälä $(\mathrm{Cu}-\mathrm{Fe}-\mathrm{Ni}-\mathrm{Co}-\mathrm{S})$ represents the second factor (Ni-ore factor) of the mafic-ultramafic rocks and the second $(\mathrm{Zn}-\mathrm{Pb})$ and fourth $(\mathrm{Cu} / \mathrm{S})$ factors have their counterparts in the third $(\mathrm{Zn}-\mathrm{Co})$ and fourth $(\mathrm{Cu}-\mathrm{Cu} / \mathrm{S})$ factors, respectively. The third factor at Telkkälä does not seem to have any equivalent in the mafic-ultramafic rocks. The high loadings on $\mathrm{Ni} / \mathrm{S}$ and $\mathrm{Ni} / \mathrm{Co}$ are included in the Ni-ore factor of the latter and do not appear as an independent factor, as is the case at Telkkälä.

The factor score distribution and, to some extent, the elemental variation in the deposit is illustrated in three sections depicted in Figs. 13. and 15. In the longitudinal section (Fig. 13.) the $\mathrm{Ni}-\mathrm{Cu}$-mineralization is heaviest in the bulge at the southeastern end of the deposit as indicated by the scores of the first factor. From there northwestwards the degree of mineralization decreases fairly sharply. Rocks with a low-grade dissemination running sub-horizontally through the orebody near its centre are also reflected in the distribution pattern.

The $\mathrm{Zn}-\mathrm{Pb}$ factor exhibits the highest intensity in the embayment of the deposit in roughly the same place as the first factor. The source of $\mathrm{Zn}$ and $\mathrm{Pb}$ is somewhat obscure. Zinc and lead invariably occur as trace elements in nickelcopper deposits. However, they are not incorporated in the nickel-ore factors but appear as a discrete factor (Häkli 1970). Consequently, in spite of the fact that these elements occur spatially with the nickel ore sulphide assemblage they must have crystallized later, possibly at a $9 \quad 7352-75$ somewhat lower temperature under hydrothermal conditions. The abundance of zinc at Telkkälä is abnormally high for a nickel deposit, in some cases exceeding $3 \% \mathrm{Zn}$ (up to $0.5 \%$ $\mathrm{Pb}$ ) which might suggest that some of it at least came from an external source. Moreover, drill sample data show that the $\mathrm{Zn}-\mathrm{Pb}$ factor score »high» actually extends beyond the boundaries of the mafic body.

The maximum of the scores of the third factor is at the northwestern end of the deposit. The sulphide dissemination at this end probably represents the early magmatic formation of sulphide blebs, which took place at a temperature somewhat higher than the crystallization of the massive and breccia ores at the southeastern end. The lower maxima in the southeastern part of the deposit are attributable to the lack of secondary alterations that elsewhere enriched the ore in sulphur and cobalt.

The Ni-Cu-ore generating process came to an end with the formation of chalcopyrite, which locally raised the copper percentage in the sulphide phase. The distribution pattern of the scores of the fourth factor indicates that this process was active mainly at the northwestern end of the deposit and also in some sub-horizontal zones throughout the orebody. According to Craig and Kullerud (1967), the phase relations in the $\mathrm{Cu}-\mathrm{Fe}-\mathrm{Ni}-\mathrm{S}$ system demonstrate that a copper-rich sulphide liquid coexists with the pyrrhotite phase at temperatures as low as $850^{\circ} \mathrm{C}$. The segregation of such a copper-rich liquid and its subsequent penetration into the fractures produced in the country rock by cooling are probably reflected in the fourth factor.

The two cross-sections reproduced in Figs. 14. and 15. illustrate the distribution of the factor scores in planes perpendicular to the section of Fig. 13. The higher variance in a vertical than in a horizontal direction, which is so apparent in these figures, is undoubtedly partly due to the sampling method employed. The spacing between the samples in a horizontal direction was 10 metres but in a vertical direction only 1 metre. 
$\mathrm{Cu}-\mathrm{S}-\mathrm{Fe}-\mathrm{Ni}-\mathrm{Co}$ factor

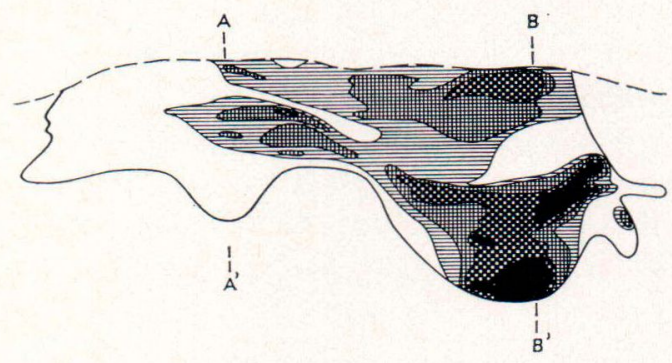

$\mathrm{Ni} / \mathrm{S}$ factor

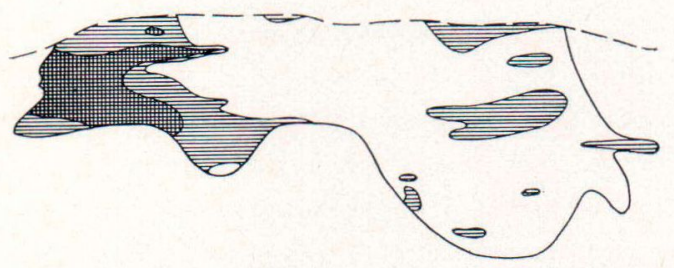

$\mathrm{Zn}-\mathrm{Pb}$ factor

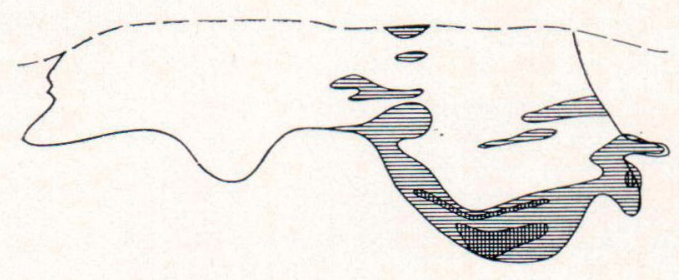

$\mathrm{Cu} / \mathrm{s}$ factor

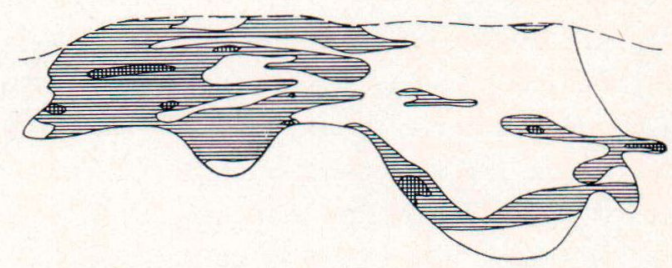

4-6

$0-2$

$>6$

Fig. 13. Factor score distributions in longitudinalC-C'section.

However, geologic observations made in the open pit support the view that, although somewhat overemphasized, the subhorizontal patterns reflect the distribution of the rock types in the deposit.

\section{Dating}

Representative samples were collected from seven genetically significant localities of the orebody for age determinations based on the lead isotope data from the sulphides. For that purpose chalcopyrite fractions were separated in hot Clerici solution from samples 1, 2, 6 and 7. The first two were from disseminations in the cummingtonite gabbro in the NW end of the mafic body and the other two from the heavily mineralized peridotite in the core of the "pipe». Specimens 4 and 5 were handpicked galena from the $\mathrm{Zn}-\mathrm{Pb}$-rich zone in the embayment of mas-
$\mathrm{Cu}-\mathrm{S}-\mathrm{Fe}-\mathrm{Ni}-\mathrm{Co}$ factor

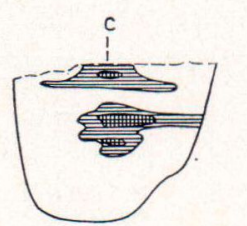

i

$\mathrm{Ni} / \mathrm{S}$ factor

$\mathrm{Cu} / \mathrm{S}$ factor
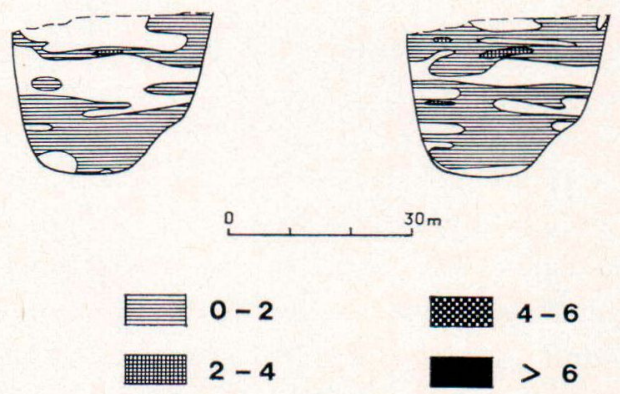

Fig. 14. Factor score distributions in transversal $A-A^{\prime}$ section. 
sive sulphides. Specimen 3 was also from this zone and contained galena grains, although too few to be hand-picked, with the consequence that in this particular case the whole sulphide fraction was analyzed.

The lead in all the samples is radiogenic and extremely so, as demonstrated by the lead isotope data compiled in Table 3 . However, the relative amount of radiogenic lead varies from sample to sample and in such a manner that the samples from the core of the deposit ( 6 and 7) are the least anomalous, whereas the samples nearest to the country rock (1 and 2 ) have extreme values.

Sample 1, which exhibits the highest anomaly, was collected from some two metres above the bottom contact of the cummingtonite gabbro with the underlying mica gneiss, and sample 2 from roughly two metres higher, which suggests that at least some of the radiogenic lead derives from the surrounding mica gneiss.

The plot of the lead isotope data is given in Fig. 16. The line through the points is a least squares fit, with a slope of 0.1125 . It was calculated assuming a two-stage evolution. The isochron gives an age of $1820 \mathrm{Ma}$ if the new decay constants (Jaffey et al. 1971) are used, or $1850 \mathrm{Ma}$ if based on the old $\mathrm{U}$ decay constants.

The date is in excellent agreement with the
$\mathrm{Cu}-\mathrm{S}-\mathrm{Fe}-\mathrm{Ni}-\mathrm{Co}$ factor

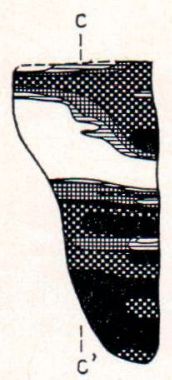

$\mathrm{Zn}-\mathrm{Pb}$ factor

\section{$\mathrm{Ni} / \mathrm{S}$ factor}

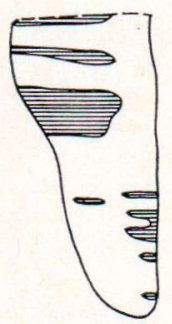

$\mathrm{Cu} / \mathrm{s}$ factor
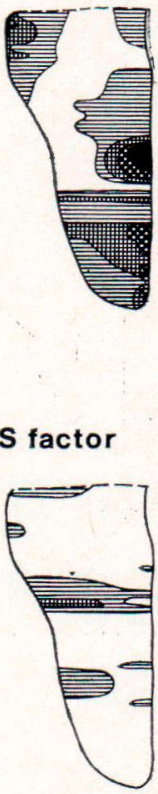

$30 \mathrm{~m}$
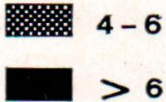

Fig. 15. Factor score distribution in transversal B-B'section.

TABLE 3

Lead isotope data for 7 sulphides from the Telkkälä deposit

\begin{tabular}{|c|c|c|c|c|}
\hline No. & Sample & ${ }^{206} \mathrm{~Pb} /{ }^{204} \mathrm{~Pb}$ & ${ }^{206} \mathrm{~Pb} /{ }^{204} \mathrm{~Pb}$ & ${ }^{207} \mathrm{~Pb} /{ }^{204} \mathrm{~Pb}$ \\
\hline 1 & $\begin{array}{l}\text { chalcopyrite from disseminated ore in cummingtonite } \\
\text { gabbro } \ldots \ldots \ldots \ldots \ldots \ldots \ldots \ldots \ldots \ldots \ldots \ldots \ldots \ldots \ldots \ldots \ldots\end{array}$ & 81.58 & 22.69 & 38.18 \\
\hline 2 & $\begin{array}{l}\text { chalcopyrite from disseminated ore in cummingtonite } \\
\text { gabbro } \ldots \ldots \ldots \ldots \ldots \ldots \ldots \ldots \ldots \ldots \ldots \ldots \ldots \ldots\end{array}$ & 34.19 & 17.34 & 38.19 \\
\hline 3 & total sulphides $\ldots \ldots \ldots \ldots \ldots \ldots \ldots \ldots \ldots \ldots \ldots \ldots$ & 20.01 & 15.91 & 38.06 \\
\hline 4 & 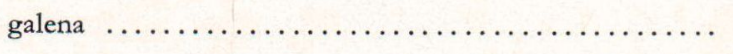 & 20.07 & 15.90 & 39.56 \\
\hline 5 & 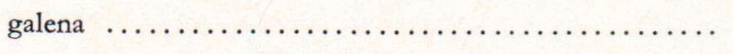 & 19.39 & 15.81 & 38.76 \\
\hline 6 & chalcopyrite from peridotite, central part of orebody & 17.57 & 15.48 & 37.42 \\
\hline 7 & chalcopyrite from peridotite, central part of orebody & 16.97 & 15.45 & 36.71 \\
\hline
\end{tabular}

The data are corrected to absolute value of CIT lead (Catanzaro 1967).

The samples were analysed in the laboratory of the Geological Survey of Finland on a 9-inch solid source mass spectrometer using a silica gel-phosphoric acid activator on single Re filament. 


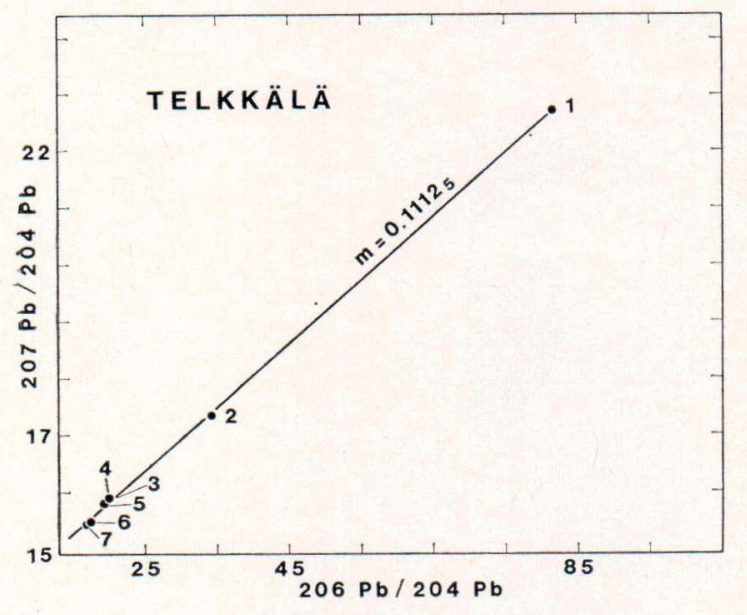

Fig. 16. The ${ }^{206} \mathrm{~Pb} /{ }^{204} \mathrm{~Pb}$ versus ${ }^{207} \mathrm{~Pb} /{ }^{204} \mathrm{~Pb}$ diagram for Telkkälä leads. According to the concept of twostage evolution the indicated slope of isochron gives an age of $1820 \mathrm{Ma}$ on the basis of the new decay constants (Jaffey et al. 1971) or $1850 \mathrm{Ma}$ if the old U decay constants are used.

Svecofennian common lead ages for sulphides (Kouvo, Kulp 1961), but younger than the radiometric $\mathrm{U}, \mathrm{Th}-\mathrm{Pb}$ ages for Svekokarelian zircons and titanites, $1900 \mathrm{Ma}$, obtained from the Kotalahti nickel deposit (Geological Survey of Finland, Ann. Rep. 1974).

Galena does not form a discrete isochron, as the few points cluster too close to each other and do not allow a meaningful line to be drawn through them. Hence, galenas are tentatively interpreted as being genetically related to and formed approximately simultanously with the nickel mineralization. However, it should be noted that if a line were drawn through the chalcopyrite points only, omitting the galena points, the numerical value of the slope would increase slightly, thereby shifting the date to 1870 Ma.

\section{Summary and conclusions}

The Telkkälä nickel ore deposit displays some features which are not easily explained. The mineragraphy, distribution of metals and sulphide minerals and the field evidence presented in this study lead to the following conclusions which, as we belive, best explain the relationships encountered at Telkkälä.

1. The nickel-copper sulphide mineralization is intimately associated with a mafic body whose composition ranges from peridotite to gabbro. The differentiates show a concentric arrangement in which the ultramafic rocks occupying the core are rimmed by gabbros.

2. The majority of the sulphides are concentrated in the structural embayment at the southeastern end of the deposit. A low- to medium-grade dissemination occurs in the cummingtonite gabbro northwest of the heavily mineralized embayment. The sulphides in the disseminated blebs are almost invariably fresh and only occasionally exhibit signs of incipient alteration. The sulphides in the embayment have been exposed to metasomatic process, due to which pyrrhotite grains have partly or completely altered into pyrite and marcasite, while at the same time numerous pentlandite grains have turned into violarite.

3. The factor analysis carried out on the geochemical data suggests that four mutually independent agents were effective during the formation of the sulphide mineralization. They gave rise to a) the dissemination in cummingtonite gabbro, b) the sulphide accumulations in the embayment including the introduction of excessive sulphur and cobalt with the subsequent alterations, c) the formation in the country rocks of chalcopyrite of the second generation and $\mathrm{d}$ ) the $\mathrm{Zn}-\mathrm{Pb}$ mineralization.

4. The relatively high abundance of nickel in pyrrhotite compared with that of the pyrrhotite in larger nickel-copper deposits (Papunen, 1970) is probably due to rapid cooling. The temperature of the deposit must have been fairly high during and immediately after the emplacement of the mafic silicate-sulphide 
melt, probably exceeding $1100^{\circ} \mathrm{C}$ (Green, Ringwood 1967), in order to produce the thermometamorphic phenomena observed in the contacts of mafic body with mica gneiss. The evidence gathered from the Telkkälä deposit has led us to the following model for the formation of the mineralization. We believe that the concentric structure of the basic body is best explained as a vent, gently tilting to the southeast, through which the mafic silicate melt discharged with appreciable amounts of sulphides in suspension. The gravitational settling concentrated sulphide liquid into the embayments at the bottom of the magma chamber where it remained mobile after the consolidation of basic rocks. At a somewhat lower temperature the increased water pressure caused brecciation and produced open spaces, which the sulphide liquid invaded forming breccia and massive ores. After the consolidation of the monosulphide phase a copper-rich sulphide liquid separated from it at a temperature exceeding $850^{\circ} \mathrm{C}$ and penetrated the contraction fractures in the country rocks, thereby giving rise to chalcopyrite veinlets. The monosulphide solid solution persisted during the cooling to at least $700^{\circ} \mathrm{C}$ (Naldrett, Kullerud 1967). Sub- sequently, pyrite, chalcopyrite, pentlandite and monoclinic pyrrhotite were formed through a succession of complicated exsolution events (Craig et al. 1967).

The dissemination in cummingtonite gabbro apparently formed at a temperature below $1000^{\circ} \mathrm{C}$ (Craig, Naldrett 1967), when the rapid crystallization of silicates prevented sulphide droplets from accumulating at the bottom of the basic body. Somewhat later, the vent introduced more sulphur and cobalt and probably also some iron, zinc and lead into embayment, thereby decreasing the Ni/S and $\mathrm{Ni} / \mathrm{Co}$ rations and generating disulphides. Partly contemporaneously but independent of the above, the low-grade $\mathrm{Zn}-\mathrm{Pb}$ mineralization developed in the embayment and in the country rock, thus closing the succession of ore-forming events. Much later, when erosion had lowered the surface close to its present level the supergene processes went into action.

Acknowledgements - We are indebted to the Outokumpu Co. for permission to publish this paper. The lead isotope determinations were made in the geochronological laboratory at the Geological Survey of Finland by Dr. O. Kouvo and Mr. Matti Vaasjoki, M. A. Discussions with Dr. O. Kouvo were fruitful and stimulating and we greatly appreciate the aid he offered us during our studies.

\section{REFERENCES}

Catanzaro, E. J. (1967) Absolute isotopic abundance ratios of three common lead reference samples. Earth and Planet. Sci. Lett. 3: 343-346.

Craig, J. R. and Kullerud G. (1967) The Cu-Fe-Ni-S system. Carnegie Inst. Wash. Yb. 66: 413-417.

Graig, J. R. and Naldrett, A. J. (1967) Minimum melting of nickeliferous pyrrhotite ores. Carnegie Inst. Wash. Yb. 66: 417-419.

Geological Survey of Finland (1974) Annual Report on the Activities for the Year 1973. English summary.

Green, D. H. and Ringwood, A. E. (1967) The genesis of basaltic magmas. Contr. Mineral. and Petrol. 15: $103-190$.
HäkLI, T. A. (1970) Factor analysis of the sulphide phase in mafic-ultramafic rocks in Finland. Bull. Geol. Soc. Finland. 42: 109-118.

Jaffey, A. H., Flynn, K. F., Glendenin, L. E., BentLEY, W. C., and Essling, A. M. (1971) Precision measurement of half-lives and specific activities of ${ }^{235}$ U. Phys. Rev. C, 4 p. 1889.

Ketola, Matrir. (1972) Some points of view concerning mise-à-la-masse measurements. Geoexploration, 10: $1-21$.

Kouvo, O. and Kulp J. L. (1961) Isotope composition of Finnish galenas. Ann. N. Y. Acad. Sci. 91: 476491. 
Naldrett, A. J. and Kullerud, G. (1967) A study of the Strathcona mine and its bearing on the origin of the nickel-copper ores of the Sudbury District, Ontario. J. Petrol. 8: 453-531.

Papunen, Herkki (1970) Sulfide mineralogy of the Kotalahti and Hitura nickel-copper ores, Finland. Ann. Acad. Sci. Fennicae A III 109.
Vorma, Atso (1965) [Map of Pre-Quaternary rocks], 3134 Lappeenranta. Geological Map of Finland, 1: 100000 .

Manuscript received, 30 October, 1974. 